OPTIMUM. STUDIA EKONOMICZNE NR 5 (77) 2015

\author{
Urszula GOLASZEWSKA-KACZAN, Marek KRUK, Anna ŚLESZYŃSKA- \\ -ŚWIDERSKA ${ }^{1}$
}

\author{
DOI: $10.15290 /$ ose.2015.05.77.12
}

\title{
ECO-LABELLING AS A TOOL OF CSR: OPPORTUNITIES AND THREATS
}

\begin{abstract}
Summary
Corporate Social Responsibility is a concept which, although it is developing for many years, it is constantly improved in both terms - theoretical and practical. In theory area are creating new definitions and new areas for action shots and in practice area are sought new instruments that could be used in pro-social activities. In this way, more and more expanding a set of tools that are available for socially responsible companies.

In this article will be discuss the eco-labeling, which is an instrument belonging to the traditional set of activities in the framework of CSR. Eco-labeling is relatively poorly described issue in literature. In practical area, we can also find deficiencies.

Analyzing the areas of corporate social responsibility calculated by ISO 26000, eco-labeling can be included into the area of the environment, fair operating practices and consumer issues. This shows how multi-dimensional issue is the use of eco-labeling. This fact creates the possibility of assessing this practices of different points of view - companies, consumers and the environment.

The purpose of this article is to identify opportunities and risks associated with the use of ecolabelling as a tool of CSR. In this article the authors will show that the activity in the area of eco-labeling not only builds the image of a socially responsible company, but also translates to specific business benefits. In addition, the authors will attempt to assess the proportion of customers for products marked with eco-labeling.

Analysis of the problem will be based on the available literature in the field of corporate social responsibility, marketing, sustainable development and environmental protection.
\end{abstract}

Key words:: ecolabelling, corporate social responsibility

\section{Introduction}

The modern business environment is continuously changing and becoming increasingly complex. It creates specific conditions for entrepreneurship, which include [Hancock, Korsten, Pohle 2003, p. 83.]:

\footnotetext{
${ }^{1}$ Dr hab. Urszula Gołaszewska- Kaczan, prof. UwB - Faculty of Economics and Management, University of Bialystok, e-mail: ulakacza@o2.pl. Marek Kruk, Ph.D. - Faculty of Economics and Management, University of Bialystok, e-mail: marek.kruk@uwb.edu.pl. Anna Śleszyńska-Świderska, M.A. - Faculty of Economics and Management, University of Bialystok, e-mail: a.sleszynska@interia.pl.
} 
- competitive Darwinism, involving steady and very strong pressure from direct and substitutive competition, as well as the ongoing emergence of new competitors;

- discontinuity of environment, which involves changing demand, technological innovation and sudden, dramatic alterations in government legislation;

- unrelenting financial pressure, requiring a growing and predictable revenue, which becomes an economic challenge and is expected by investors;

- unforeseeable threats - a universal hazard for international companies that are ever more vulnerable to natural disasters, unstable geopolitical situation, and other market shocks.

These circumstances force entrepreneurs to undertake specific actions in order to alleviate risk, diminish the threats, and at the same time enhance the competitive position of their companies. Y. Allaire and M. Firsirotu claim that in order to reduce the uncertainty and limit a company's sensitivity to external influence, managers can resort to the political method. It involves creating or controlling the future of a company through subordination or elimination of the sources of uncertainty. Among the tools used in the political method is social responsibility [Allaire, Firsirotu, 2000, p. 322].

The concept of corporate social responsibility arose from a new approach to objectives of a company and to the persons or groups in whose interests companies operate. Instead of being merely regarded as institutions established to pursue the interests of their owners, enterprises are gradually seen as places which should also satisfy the needs of other stakeholders. Social responsibility assumes that it is possible - and profitable - to undertake such actions which contribute to achieving social welfare goals, in the broad sense of the term. Moreover, those actions are voluntary in nature and go beyond the scope of legal provisions.

Companies can implement socially responsible measures within various areas and towards different stakeholders, using a wide range of instruments, methods, and techniques.

The purpose of the paper is to present eco-labelling as a tool of social responsibility and to indicate the benefits which could be attained from its use, both for companies and for various groups of stakeholders. The authors aim wish, among other things, to prove that socially responsible policies can not only improve the image of a company, but that they can also translate into tangible business outcomes.

The analysis is based on the available literature on corporate social responsibility, marketing, sustainable development, and environmental conservation.

\section{Position of Eco-Labelling in the Concept of Social Responsibility}

Corporate social responsibility has been for some time in the focus of research carried out by scholars from various fields of management. And yet, no universally accepted definition of the idea has been established. The first attempt at such a definition was made in 1933 by A. Carnegie in The Gospel of Wealth [Carnegie, 1993], where the author described social responsibility using the principles of charity and 
stewardship. Over the following years, new approaches to the notion emerged. In particular, the 1970s and 1980s saw an increased number of endeavours to describe social responsibility. It is in that period that A. B. Carrol proposed that the concept encompassed the economic, legal, ethical, and discretionary responsibilities that society expected businesses to assume at a given time [Carroll, 1981, p. 50.]. The twentyfirst century has brought a different interpretation of the term, not merely emphasising the types of obligations that companies have, but rather focusing on the dialogue with stakeholders. A formal definition provided by Canadian Democracy and Corporate Accountability Commission in 2001 states that the term denotes the overall relationship of a corporation with all of its stakeholders [Canadian Democracy and Corporate Accountability Commission, 2001, p. 132].

The scope of this paper is insufficient for an in-depth analysis of the evolving approaches to social responsibility. It should be noted, however, that the debate is still ongoing, which proves that the topic is both important and relevant, and that the changing circumstances in which businesses function make it necessary to reconsider the interpretation of the idea.

An attempt to standardise the definition of social responsibility was made in 2010, when the ISO 26000 norm was developed. The standard is designed to provide a uniform understanding of the term, irrespective of the conditions in which an enterprise operates.

According to the document, social responsibility is the responsibility of an organisation for the impact of its decisions and activities on the society and the environment, through transparent and ethical behaviour that [Electronic document, access mode: http:/ /www.pkn.pl/iso-26000, retrieved: 15.10.2014]:

- contributes to sustainable development, including the health and the welfare of society;

- takes into account the expectations of stakeholders;

- $\quad$ is in compliance with applicable law and consistent with international norms of behaviour;

- $\quad$ is integrated throughout the organisation and practised in its relationships.

This approach assumes that the notion is relevant for all entities, regardless of their nature and mode of operation. As the website of the National Standards Body in Poland informs, social responsibility applies to all kinds of organisations: public, private and non-profit, notwithstanding size or location, both those functioning in developed and developing countries. Moreover, it is not limited to corporate social responsibility. This represents a step forward in comparison to the earlier definitions, which mostly associated social responsibility with business ventures. ISO 26000 also provides guidance to seven areas in which socially responsible activity may be undertaken [Electronic document, access mode: http://www.26k-estimation.com/html/ user_guides_iso_26000.html\#user-guides, retrieved: 15.10.2014]. These include:

- organisational governance: management that takes into account social interest, rights of stakeholders, and social norms;

- human rights: respect for people and their dignity;

- labour practices: responsible management of human resources; 
- environment: actions for the protection of the natural environment, in the broad sense of the term;

- fair operating practices: observing the principles of fair competition;

- consumer issues: honest and transparent behaviour of companies towards consumers;

- community involvement and development: actions for the benefit of local communities.

The present paper focuses mainly on 'consumer issues'. ISO 26000 enumerates the following [Electronic document, access mode: http://ecodialog.pl/sites/default/ files/.discovering_iso_26000PL.pdf, retrieved: 15.10.2014]:

- Issue 1: Fair marketing, factual and unbiased information and fair contractual practices.

- Issue2: Protecting consumers' health and safety.

- Issue 3: Sustainable consumption.

- Issue 4: Consumer service, support, and complaint and dispute resolution.

- Issue 5: Consumer data protection and privacy.

- Issue 6: Access to essential services.

- Issue 7: Education and awareness.

The above are, of course, only examples of issues which in practice may be accompanied by a number of other endeavours.

Eco-labelling, which is the focus of the present paper, can be seen as part of Issue 1, i.e. as an element of unbiased information addressed to customers, as well as part of Issue 7 , being an excellent means of educating customers and enabling them to make conscious and informed choices.

Interestingly, eco-labelling can also be analysed from the point of view of fair operating practices, since it is an instrument of ethical competition policy, and as a way to encourage protection of the environment and cleaner production.

\section{The notion of eco-labelling}

As mentioned earlier, the idea of eco-labelling is relevant to several important aspects of social responsibility. On the one hand, customers are provided with additional, although not legally required, information on products. On the other hand, it boosts the promotion of eco-friendly products, which is beneficial to the natural environment. Moreover, eco-labelling contributes to improving the standards of market competition.

The origin of eco-labelling can be traced back to the idea of using certain prefixes in front of product names, in particular such as 'eco-' or 'bio-'. The idea of using it wasn't correlated with meaning of this prefixes. From marketing point of view such a product should be identified by buyers as natural and ecological, so more healthy to the human body. Such a message expressed was not, however, explicit enough as customers' expectations were far more specific. It was in the 1970s when special 
ecological markings started to be used on the least eco-unfriendly products. The principles of ecological certification were established by many international organisations, e.g. the European Communities, the World Trade Organisation (WTO), the United Nations Environmental Programme (UNEP), and the International Standardization Organisation (ISO). The first countries to introduce eco-labelling included: Germany (1978), Canada (1988), the Nordic Council States (1989), Austria (1991), and the Netherlands (1992).

The introduction of eco-labelling made it possible to achieve the following effects [Gallastegui, 2012, pp. 316-317.]:

1. the opportunity to emphasise the influence of consumption on the natural environment through appropriate, clear and informative labelling of products. The ability to create more sustainable consumption, thanks to the growing customer awareness;

2. the involvement of companies, governments and other institutions in developing more environmentally benign products;

3. the initiation of competitive processes based on using labels which provided customers with considerable added value.

Another upside of eco-labelling is that it provides comprehensive information on production, packaging, distribution, consumption, and waste management.

The various eco-labelling schemes can be classified into three broad types [OECD, 1997, pp. 9-10.]:

- $\quad$ type I labels indicate the quality of products in relation to the environment and in comparison with others in the same category; type I labels aim to encourage more sustainable consumption through the development of pro-ecological habits. These labels are voluntary and are awarded by third parties, often financially supported by governmental institutions. Their purpose is to certify that both the manufacturing process and the entire life-cycle of a product are respectful of the environment;

- $\quad$ type II labels are self-declarations made by producers, importers, or distributors to inform buyers about the environmental impact of goods, and refer to specific attributes of the products;

- $\quad$ type III labels, the least common ones, provide information on the quantitative aspects of products and are based on independently verified indicators.

Type I eco-labels are by far the most frequently used. This seems to be caused by the fact that they are granted by independent certifying institutions (unlike type II labels) and according to relatively straightforward certification criteria (very much in contrast to type III labels).

Eco-labelling can use a variety of criteria. Customers might regard the following as the most important [OECD, 1997, p. 126]:

- presence of toxic substances in products;

- presence of artificial additives in products;

- greenhouse gases emissions resulting from manufacturing, shipping and consumption of products; 
- $\quad$ resources used in production process;

- $\quad$ waste generated as a result of production process;

- non-renewable resources used for manufacturing goods;

- the amount of energy needed for production;

- $\quad$ water pollution caused by production;

- geographical origin of products;

- geographical origin of resources;

- $\quad$ use of child labour;

- $\quad$ spatial location of production (local manufacturing).

Companies venture into eco-labelling schemes and bear the costs of certification procedures to be entitled to using the labels on their products because they count on certain benefits. The major potential advantages include the following [Gallastegui, 2012, p. 318.]:

- consumers, even if they wish to learn about the environmental impact of a product, do not devote much time to searching for relevant information, and thus are willing to trust a label which is reliable and which meets their expectations;

- $\quad$ appropriate labelling, satisfying the preferences of buyers, can help to boost the image of a company and lead to an increase in the volume of sales;

- labels can draw the buyers' attention to environmental issues;

- participation in eco-labelling schemes can prompt direct involvement in nature conservation activities

From this point of view, eco-labelling represents a tool for achieving a competitive advantage over products which are not marked with ecological labels.

The positive influence of eco-labelling is also evident on the social level. The following benefits should be emphasized [Electronic document, access mode, https://www.iisd.org/business/markets/eco_label_benefits.aspx, retrieved: 18.09.2014]:

1. Facilitating consumer choices.

Eco-labelling is an efficient way to inform customers about the environmental impact of selected products. It enables people to discriminate against products which are harmful to the environment and to choose those which are more compliant with environmental protection requirements. Eco-labelling raises customers' awareness of the benefits of certain products in terms of, e.g., energy efficiency or waste reduction.

2. Promoting economic efficiency.

Eco-labelling is usually less costly than regulatory investigations. By allowing customers and manufacturers to take ecologically responsible decisions, the need for formal regulations is reduced to a minimum. This is advantageous both for the government and for the industry.

3. Stimulating market development.

When customers choose ecological goods, they directly influence supply and demand for these products, sending a signal to the market that being ecologically conscious is profitable. 
4. Encouragement for continuous improvement.

The dynamic market for eco-labelled products encourages manufacturers to keep improving the state of the natural environment. Customers can expect that the negative impact of industrial products on the environment will gradually be lessened.

5. Promotion of certification.

Certification schemes confirm that products meet specific ecological standards. They provide customers with tangible evidence for the advisability of consumption from the viewpoint of environmental protection. Therefore, certification helps educate customers and strengthens competition mechanisms among manufacturers. Because certified products are easily identifiable by visible logos, they stand out on shop shelves.

6. Assistance in monitoring

Another benefit of official eco-labelling programmes is the fact that all kinds of irregularities are easier to detect. This is convenient for both competitors and customers because they are better able to assess the validity of potential damages action.

The phenomenon of eco-labelling is an ambiguous one. It can be regarded from various points of view. Nevertheless, its effectiveness always depends on the consumers, whose perception and experience allow them to variously evaluate eco-labelled products and thus modify their market behaviour towards this type of goods.

\section{Consumer attitudes towards eco-labelling}

Both theoreticians and practitioners have long been exploring the factors that shape the behaviour of consumers. Just several years ago, it was underlined that price and quality were the key determinants which influenced purchase decisions, closely followed by brand loyalty. Although price and quality do remain significant factors, the steady trend towards ecologically sound consumption that finds its embodiment in actions for reducing environmental impact causes a rise in the role of other considerations.

Eco-labelling can, therefore, become a sort of marketing strategy aimed at the promotion of sustainable consumption based on natural products whose manufacturing is consistent with the principles of conservationism. Furthermore, eco-labels are a marketing tool which can be used to stimulate the development of organic products market [Atănăsoaie, 2013, p. 122.].

An analysis of the marketing side of eco-labelling should acknowledge that it is also identified with the concept of social marketing, whose objective is to support initiatives intending to solve social problems [Cooper, Ludlow, Clift, 2012, p. 36.] such as, e.g. the preservation of natural resources for future generations.

However, if eco-labelling is to fulfill its functions, it must be intelligible to customers. Unfortunately, information concerning the environmental impact of prod- 
ucts reaches customers from many sources and can be incoherent or contradictory. Consumers who are overwhelmed by confusing messages might, as a result, make incorrect decisions and buy non-ecological products, in spite of the best intentions to purchase environmentally friendly ones [Electronic document, access mode: http://www.europarl.europa.eu/RegData/docs_autres_institutions/commission_e uropeenne/swd/2013/0112/COM_SWD(2013)0112_PL.pdf, retrieved: 10.10. 2014].

In order to take full advantage of the potential of eco-labelling, firms and institutions which venture to certify their products and services must focus on activities that would influence customers during the actual purchasing process [Atănăsoaie, 2013, p. 125.]. The first objective is to arouse interest, which should be a consequence of educational efforts directed at buyers to raise their awareness of the benefits signified by particular labels. In many countries, several eco-labels are present in the market, which allows consumer to find out what each of them means. Besides, they need to have knowledge about the criteria that must be met to obtain the right to use each label. When the values behind eco-labels are properly understood, they gain credibility, which is then transferred on the labelled products. Any difficulties to read and interpret an eco-label can discourage the potential buyers of the products they mark and even inspire aversion towards eco-labelling as such.

However, those eco-labels which are familiar to customers and generate favourable associations increase customers' readiness to make a purchase, enhance the buyers' perception of a product's quality, and lower the sensitivity to price (which is usually higher than in the case of similar, but unlabelled goods). If customers are provided with necessary and reliable information regarding eco-labelling, they will be more likely to purchase an eco-product [Bostrom, Klintman, 2011, pp. 35-38.] and more willing to pay attention to the label the product comes with. Bona fide information on ecolabels seems to be, therefore, a signal sent to consumers and prompting them to select ecologically-branded products [Dočekalová, Straková, 2011, p. 1248.].

Consumers' attitudes vary widely: some value only those labels which comply with strict standards, for others the important thing is whether the certification is granted by an institution involved in environmental protection, by an industry, or by the government. The attitude adopted by consumers can affect their purchase intentions. The higher the awareness of the benefits gained from buying eco-labelled products, the stronger the accompanying intentions. If the product meets the expectations, further purchases can be anticipated, reinforced by the conviction of its positive impact on the buyer and his or her family, as well as other people and the natural environment. In this situation, loyalty towards products labelled as ecological is created, which is interpreted as a positive effect of eco-labelling.

Constructing the ecological awareness among consumers is a long-term, and quite difficult, process. It requires educational efforts targeted at the youngest generations. According to the theory of consumer behaviour, people are reluctant to alter their habits and preferences related to consumption. This is why it is so vital to begin shaping the ecological awareness among the youngest consumers and to continue doing so in their later years, increasing the chance that many buyers will, before acquiring a product, carefully reflect on its environmental impact. 
The results of a 2012 research conducted by Eurobarometer entitled 'Attitudes of Europeans towards building the single market for green products' demonstrate that in the entire EU, $80 \%$ of the consumers buy eco-labelled products, and are eager to buy more. Upwards of a half of the purchasers (54\%) are occasional buyers, while fewer than a guarter $(26 \%)$ regularly acquired ecological products. Meanwhile, only $15 \%$ of the consumer did not buy eco-labelled goods at all. As many as $95 \%$ of those who purchase ecological products were of the opinion that they contributed to environmental conservation. What is more, $55 \%$ emphasised that those products were relatively good value for money [Electronic document, access mode: http://ec.europa.eu/public_opinion/flash/fl_367_sum_en.pdf, retrieved: 11.10.2014].

CHART 1.

Trust of European consumers towards information on environmental impact provided by green product labels in 2009 (in \%)

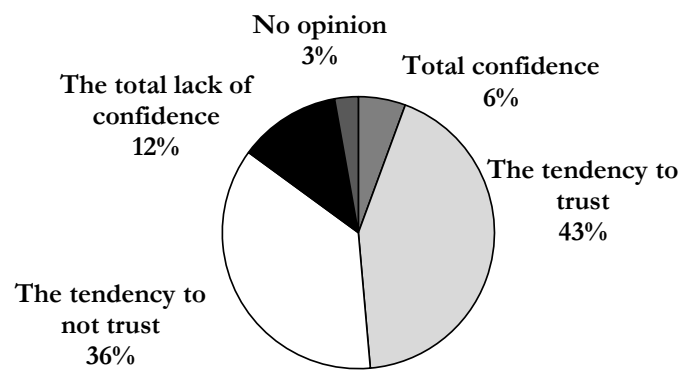

Source: author's own work based on [electronic document, access mode: http://ec.europa.eu/ public_opinion/flash/fl_367_sum_en.pdf, retrieved: 11.10.2014].

Although a large percentage of the surveyed consumers declared that they bought eco-labelled products, a substantial number of them did not actually believe the environmental impact information given on the labels of green products (see Graphs 1 and 2). An ideal consumer does not need eco-labelling to know whether a product is environmentally sound. He or she is like a fashion connoisseur, capable of recognising quality items without having to consult the labels. For ordinary customers, however, eco-labelling is like a handbook which they need to guide them in their decisionmaking. What adversely affects people's attitudes to eco-labelling is distrust towards the information eco-labels convey. An average consumer may find it difficult to judge, merely by looking at the label, which products are less harmful to the environment. That is why trust is absolutely central to the idea of eco-labelling [Dočekalová, Straková, 2011, p. 1249].

In 2012, just above a half of the consumers trusted the information they found on product labels $(52 \%)$. Compared to 2009 , this is but a slight increase (3 p.p). In 2012, 
nearly half of the consumers did not trust eco-labels (47\%), which accounts for a mere one-percentage points drop in relation to 2009.

CHART 2.

Trust of European consumers towards information on environmental impact provided by green product labels in 2012 (in \%).

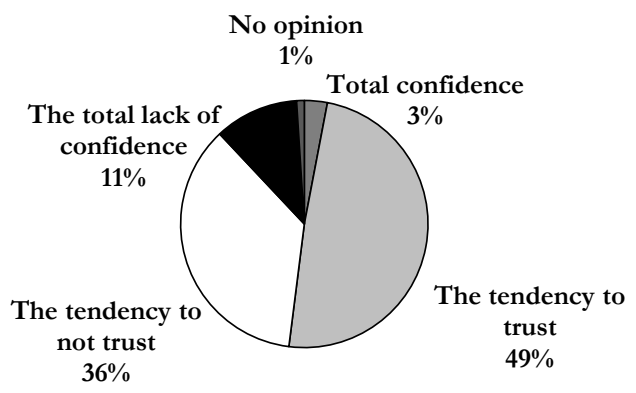

Source: author's own work based on author's own work based on [Electronic document, access mode: http://ec.europa.eu/public_opinion/flash/fl_367_sum_en.pdf, retrieved: 11.10.2014].

The distrust of eco-labels is primarily caused by the incomprehensibility and insufficiency of information placed on products. Almost six out of ten of the surveyed European consumers $(59 \%)$ believed that labels do not provide enough information regarding the environmental impact of products, and thus there were no grounds to regard them as fully ecological. Furthermore, one third of EU consumers (32\%) thought that eco-labels on some products were unclear and illegible [Electronic document, access mode: http://ec.europa.eu/public_opinion/flash/fl_367_sum_en.pdf, retrieved: 14.10.2014].

As a result, there is a growing conviction among consumers that enterprises simply compete with one another in terms of information included in eco-labels, instead being of genuinely involved in environmental efficiency [Electronic document, access mode: file://C:/Users/Enigma/ Downloads/COM_2013_196_PL_ACTE_f.pdf, retrieved: 14.10 .2014$]$.

Customer awareness of the existence of an eco-label is a necessary condition for the label's effectiveness in the purchase decision-making process. This awareness means that consumers realised that such a label exists, what it looks like, and what it means. Recognising an eco-label is not tantamount to understanding its significance. Consumers will take an eco-label into consideration in purchasing decisions only when it inspires their confidence. Many surveys suggest that consumers are sceptical about eco-labels. What is interesting, they are more willing to take them into account in the decision-making process if the information they include comes from public and other independent sources, rather than from the sellers and manufacturers. Apart from trust and awareness, another necessary condition for a positive attitude towards eco-labelling is the belief that paying attention to ecological markings helps buyers achieve their own 
goals associated with purchasing a given product [Electronic document, access mode: [Thogersen, 2000, pp. 288-289.].

A survey commissioned by the Ministry of the Environment, and conducted by PBS in 2013, reveals that a majority of Polish consumers hardly ever took any notice of the ecological labels on the products they bought (Table 1).

Analysis of the data from Table 1 shows that between the years 2011-2012 and 2013 the proportion of consumers who did not pay any attention to ecological labelling increased, while the percentage of those who did so always and often grew slightly. Overall, it can be said that more than one third of the consumers had a habit of noticing eco-labels on products. The results of the 2013 survey do not differ in any significant way from the outcomes of the 2011-2013 study.

TABLE 1.

Consumers who paid attention to ecological and environmental labels when making purchases; years 2011-2013 (in \%)

\begin{tabular}{|c|c|c|c|c|c|}
\hline \multirow{2}{*}{ Year } & \multicolumn{5}{|c|}{$\begin{array}{c}\text { Respondents' replies to question: How often do you pay attention to } \\
\text { ecological and environmental labels (in the context of shopping and }\end{array}$} \\
\cline { 2 - 6 } & Always & Often & Rarely & Never & Hard to say \\
\hline 2013 & 6 & 30 & 39 & 23 & 2 \\
2012 & 6 & 30 & 37 & 23 & 4 \\
2011 & 5 & 29 & 42 & 19 & 4 \\
\hline
\end{tabular}

Source: author's own work based on: [Electronic document, access mode: https://www.mos.gov.pl/g2/big/2013_12/ee41d9c93bc700729faf03103120a38c.pdf, retrieved: 14.10.2014].

Consumers' attitude towards eco-labelling depends on a number of factors, such as age, education, place of residence. These interdependencies are presented in Table 2.

TABLE 2

Percentage of consumers who paid attention to eco-labelling according to selected socio-demographic characteristics (in 2013)

\begin{tabular}{|c|c|c|c|c|c|c|}
\hline \multicolumn{7}{|c|}{ Characteristic } \\
\hline \multirow[t]{2}{*}{ Age } & $\begin{array}{l}15-19 \\
\text { years }\end{array}$ & $\begin{array}{l}20-29 \\
\text { years }\end{array}$ & $\begin{array}{l}30-39 \\
\text { years }\end{array}$ & $\begin{array}{l}40-49 \\
\text { years }\end{array}$ & $\begin{array}{l}50-59 \\
\text { years }\end{array}$ & $\begin{array}{l}60 \text { years } \\
\text { and more }\end{array}$ \\
\hline & 43 & 31 & 40 & 43 & 35 & 30 \\
\hline \multirow{2}{*}{$\begin{array}{c}\text { Educational } \\
\text { level }\end{array}$} & Primary & Vocational & Secondary & University & - & - \\
\hline & 34 & 26 & 40 & 50 & - & - \\
\hline \multirow{2}{*}{$\begin{array}{l}\text { Place of } \\
\text { residence } \\
\text { (number of } \\
\text { inhabitants) }\end{array}$} & Village & $\begin{array}{l}\text { Town up } \\
\text { to } 20,000\end{array}$ & $\begin{array}{c}\text { Town } \\
20,000- \\
100,000\end{array}$ & $\begin{array}{c}\text { Town } \\
100,000- \\
500,000\end{array}$ & $\begin{array}{c}\text { Town } \\
\text { above } \\
500,000\end{array}$ & - \\
\hline & 36 & 47 & 41 & 30 & 30 & - \\
\hline
\end{tabular}

Source: author's own work based on: [Electronic document, access mode: https://www.mos.gov.pl/g2/big/2013_12/ee41d9c93bc700729faf03103120a38c.pdf, retrieved: 14.10.2014]. 
Analysis of Table 2 reveals that ecological markings on products were most frequently noticed by the youngest consumers, aged 15-19 (43\%), and those aged 40-49 $(43 \%)$, with university education and living in towns inhabited by more than 20,000 people. The customers who took the least notice of eco-labels comprised persons aged $20-29(31 \%)$, with vocational education (26\%), and those who lived in towns with more than 100,000 inhabitants.

Moreover, a 2012 survey into customer attitudes proved that it is men rather than women that were more often indifferent to eco-labelling: only $20 \%$ of them paid attention to ecological labels ( $26 \%$ of the women). Also, the less well-off consumers failed to check whether the products they bought had eco-labels (35\%). Those whose financial situation was better were ready to pay more for eco-labelled goods (only $8 \%$ of them had never done it), and did so more frequently than the less wealthy [Electronic document, access mode: https://www.mos.gov.pl/g2/big/ 2012_11/037ac15934792054904ccafce588677c.pdf, retrieved: 16.10.2014].

To conclude, it can be said that consumers constitute a force to be reckoned with and can exert considerable influence on enterprises as far as eco-labelling is concerned. Although using ecological labels is voluntary, by choosing environmentally friendly goods consumers can encourage manufacturers to increase their efforts to obtain ecological certification for their products. In this way, ecological attitudes can be enhanced not only by the fact that some consumers purchase eco-labelled products, but also by that fact that producers make use of eco-labelling.

Consumer opinions on eco-labelling may vary, but it can certainly be said that a growing number of people are ready for a radical change in consumption patterns in order to minimize its negative impact on the environment [Bostrom, Klintman, 2011, p. 1-2.], and that the attitude towards eco-labelling will consequently improve. It is essential that consumers are continually informed about ecological labels that can be found on retail items and about their meaning. Moreover, they should be assured that eco-labelled products do not necessarily have to be more expensive and that not all companies exploit eco-labelling as a competition tool.

\section{Conclusion}

To sum up, it must be said that eco-labelling is an important instrument for socially responsible business. Its application can bring benefits to customers, the natural environment, and companies themselves. One should note, however, that for these benefits to be achieved, an educational campaign is needed both to raise public awareness as regards conservation of the environment and to familiarise a wider audience with the signals conveyed by eco-labels. As research indicates, in spite of the fact that many European consumers purchase eco-labelled products, a large number of them do not believe in the credibility of the provided information. It seems, therefore, necessary that consumers become better acquainted with the process of acquiring ecological certificates and the requirements which must be met by companies wishing to obtain the right to use eco-labels. As for Polish consumers, who often entirely disregard ecological 
markings, it seems crucial that general knowledge of environmental issues is reinforced. Only after these obstacles have been overcome, will it be possible for eco-labelling to fulfill the functions which are attributed to it.

\section{References}

Allaire Y., Firsirotu M. 2000 Myślenie strategiczne, PWN, Warszawa.

Atănăsoaie G. S. 2013 Eco-Label and its Role in the Development of Organic Products Market, "Economy Transdisciplinarity Cognition", Vol. 16, Issue 1.

Bostrom M., Klintman M. 2011 Eco-Standards, Product Labeling and Green Consumerism, Palgrave Macmillan, Basingstoke.

Canadian Democracy and Corporate Accountability Commission, 2001, An Overview of Issues.

Carnegie A. 1933 The Gospel of Wealth, Garden City.

Carroll A. B. 1982 A Three-Dimensinal Conceptual Model of Corporate Perfomance, [in:] W. R. Allen, L. K. Bragaw, Social Forres and the Manager. Readings and Cases, John Wiley\& Sons, New York (et al.).

Cooper T., Ludlow M., Clift T. 2012 Examining the Role of Eco-Labels in Changing the Approach to Sustainability in the Commercial Fisheries, Greener Management International, Issue 57.

Dočekalová M., Straková J. 2011 The Influence of the Eco-Labelling on Consumer Behavior in the Crech Republic and Slovakia, "Economics and Management", 16,

Electronic document, access mode: [file://C:/Users/Enigma/Downloads/COM_ 2013_196_PL_ACTE_f.pdf, retrieved: 14.10. 2014].

Electronic document, access mode: [http://ec.europa.eu/public_opinion/flash/fl_367_ sum_en.pdf, retrived: 11.10.2014].

Electronic document, access mode: [http://ecodialog.pl/sites/default/files/discovering iso_26000PL.pdf, retrieved: 15.10.2014].

Electronic document, access mode: [http://www.26k-estimation.com/html/user_ guides_iso_26000.html\#user-guides, retrieved: 15.10.2014].

Electronic document, access mode: [http://www.europarl.europa.eu/RegData/docs_ autres_institutions/commission_europeenne/swd/2013/0112/COM_SWD(201 3)0112_PL.pdf, retrieved; 10.10. 2014].

Electronic document, access mode: [http://www.pkn.pl/iso-26000, retrieved: 15.10.2014].

Electronic document, access mode: [https://www.iisd.org/business/markets/eco_label_ benefits.aspx, retrieved: 18.09.2104.].

Electronic document, access mode: [https://www.mos.gov.pl/g2/big/2012_11/ 037ac15934792054904ccafce588677c.pdf, retrieved: 16.10.2014].

Gallastegui I. G. 2012 The Use of Eco-labels: A Review of the Literature, "European Environment", No. 12.

Hancock R., Korsten P., Pohle G. 2003 On Demand Business: the New AGENDA FOR Value Creation, An IBM Institute for Business Value Futures Series, [in:] 
P. Banaszyk, Zmienność zarzadzania strategicznego przedsiebiorstwem, Wydawnictwo Uniwersytetu Ekonomicznego w Poznaniu, Poznań 2011.

OECD 1997 Eco-Labelling: Actual Effects of Selected Programmes, Organisation For Economic Co-Operation And Development, Paris.

Thogersen J. 2000 Psychological Determinants of Paying Attention to Eco-Labels in Purchase Decisions: Model Development and Multinational Validation, "Journal of Consumer Policy" 23. 